\title{
Effect of estrogen receptor $\beta$ agonists on proliferation and gene expression of ovarian cancer cells
}

\author{
Susanne Schüler-Toprak ${ }^{1 *}$, Christoph Moehle ${ }^{2}$, Maciej Skrzypczak ${ }^{3}$, Olaf Ortmann ${ }^{1}$ and Oliver Treeck ${ }^{1}$
}

\begin{abstract}
Background: Estrogen receptor (ER) $\beta$ has been suggested to affect ovarian carcinogenesis. We examined the effects of four ER $\beta$ agonists on proliferation and gene expression of two ovarian cancer cell lines.

Methods: OVCAR-3 and OAW-42 ovarian cancer cells were treated with the ER $\beta$ agonists ERB-041, WAY200070, Liquiritigenin and $3 \beta$-Adiol and cell growth was measured by means of the Cell Titer Blue Assay (Promega). ER $\beta$ expression was knocked down by transfection with specific siRNA. Additionally, transcriptome analyses were performed by means of Affymetrix GeneChip arrays. To confirm the results of DNA microarray analysis, Western blot experiments were performed.

Results: All ERß agonists tested significantly decreased proliferation of OVCAR-3 and OAW-42 cells at a concentration of $10 \mathrm{nM}$. Maximum antiproliferative effects were induced by flavonoid Liquiritigenin, which inhibited growth of OVCAR-3 cells by $31.2 \%$ after 5 days of treatment, and ERB-041 suppressing proliferation of the same cell line by $29.1 \%$. In OAW-42 cells, maximum effects were observed after treatment with the ERß agonist WAY200070, inhibiting cell growth by 26.8\%, whereas ERB-041 decreased proliferation by $24.4 \%$. In turn, knockdown of ERß with specific siRNA increased cell growth of OAW-42 cells about 1.9-fold. Transcriptome analyses revealed a set of genes regulated by ERß agonists including ND6, LCN1 and PTCH2, providing possible molecular mechanisms underlying the observed antiproliferative effects.
\end{abstract}

Conclusion: In conclusion, the observed growth-inhibitory effects of all ER $\beta$ agonists on ovarian cancer cell lines in vitro encourage further studies to test their possible use in the clinical setting.

Keywords: Estrogen receptor beta, Ovarian cancer, Estrogen receptor beta agonists

\section{Background}

Ovarian cancer is the fifth most common cause of death because of cancer in women and is the leading cause of death from gynaecological malignancy in the developed world [1]. Due to missing screening methods and its aggressive behaviour, a vast number is diagnosed at an advanced stage [2]. Steroid hormones have an influence on ovarian cancer cells [3] and it has been shown that 40$60 \%$ of ovarian cancers express estrogen receptor (ER) $\alpha$ $[4,5]$. In advanced stages the selective estrogen receptor modulator tamoxifen is used in patients as a well-

\footnotetext{
*Correspondence: sschueler@caritasstjosef.de

'Department of Obstetrics and Gynecology, University Medical Center

Regensburg, Landshuter Str. 65, 93053 Regensburg, Germany

Full list of author information is available at the end of the article
}

tolerated and also effective treatment [6-8]. Moreover, use of peri- and postmenopausal hormone therapy has been shown to increase ovarian cancer risk [9]. One extra ovarian cancer case per 1000 users can be observed in women who use hormone therapy for 5 years after the age of 50 years [9].

Investigating the underlying mechanisms, it is inevitable to consider the two ER types, ER $\alpha$ and $\beta$. So far, little is known about the molecular mechanisms of ER $\beta$ function in ovaries and ovarian cancers. However, it has been shown that both receptor types exert different biological functions $[10,11]$. Given that ER $\beta$ is able to counteract ER $\alpha$ signaling in some settings, loss of ER $\beta$ is thought to enhance $E R \alpha$-mediated proliferation of hormone-dependent cancer cells [12]. Moreover, the 
influence of ERb signaling on apoptosis pathways has been shown [13].

Comparing normal ovarian tissue with epithelial ovarian cancers, a loss of ER $\beta$ expression and a decrease in $E R \beta / E R \alpha$ ratio can be observed [14-16]. Furthermore, in metastases of ovarian cancers a complete loss of ER $\beta$ was observed, whereas in the corresponding primary tumors low expression levels were still measurable [15]. A positive correlation of ER $\beta$ expression with survival has been shown in ovarian cancer patients as well as animal models $[17,18]$.

In vitro studies on other hormone-dependent tumors as breast and prostate cancers revealed a tumor suppressive role of ER $\beta[10,19]$. Fewer reports suggest that this receptor plays a similar role in ovarian cancer. Recently, we investigated the effect of ER $\beta$ overexpression on the SK-OV-3 ovarian cancer cells. Particularly overexpression of ER $\beta 1$ inhibited growth and motility of these cells and induced apoptosis. In addition, we observed specific changes in gene expression. Interestingly, the antitumoral effects of ER $\beta$ were independent of estradiol and functional ER $\alpha$. However, we were able to show an increased transcription of cyclin-dependent kinase inhibitor 1, a decrease in cyclin A2 transcripts and an upregulation of fibulin 1c [20].

In another study, proliferation of ER $\alpha$ expressing BG - 1 ovarian cancer cells decreased after reintroduction of ER $\beta$ expression [17]. An increased expression of ER $\beta$ was associated with a decreased number of cells in $\mathrm{S}$ phase, whereas more cells were found in the $\mathrm{G} 2 / \mathrm{M}$ phase. Also the cell cycle regulators cyclin D1 and A2 were affected by ER $\beta$ expression. When ER $\beta$ was reintroduced, total retinoblastoma $(\mathrm{Rb})$, phosphorylated $\mathrm{Rb}$ and phospho-AKT content decreased. A part of the antiproliferative effect of ER $\beta$ was explained by the strong inhibition of $E R \alpha$ activity and expression by $\operatorname{ER} \beta[17,21]$. To examine the role of ER $\beta$ in a more physiological model of ovarian carcinogenesis, Bossard et al. orthotopically transplanted ER $\beta$ expressing ovarian cancer cells in ovaries of Nude mice, which reduced both tumor growth and the presence of tumor cells in sites of metastasis, and led to improved survival [17].

The suggested role of ER $\beta$ as tumor suppressor and the observed decrease of expression in ovarian cancer cells raise the question, whether ER $\beta$ expression in these cells might be high enough to make this receptor a potential target in ovarian cancer therapy. Thus, we investigated the effect of ER $\beta$ agonists on proliferation and gene expression of two ovarian cancer cell lines.

\section{Methods}

\section{Material}

The human ovarian cancer cell line OVCAR-3 was obtained from American Type Culture Collection (ATCC
\#HTB-161, Manassas, USA), and OAW-42 ovarian cancer cells were obtained from Sigma Aldrich (\#85073102, St. Louis, USA). The cells were maintained in phenol red-free DMEM culture medium that was obtained from Invitrogen (Karlsruhe, Germany) containing FCS that was purchased from PAA (Pasching, Austria). RNeasy Mini Kit was obtained from Qiagen (Hilden, Germany). Transfectin reagent was obtained from BioRad (Hercules, USA). OptiMEM medium were purchased at Invitrogen (Karlsruhe, Germany). ESR2 and control siRNAs were from Ambion (Life Technologies, USA). Serum Replacement 2 (SR2) cell culture supplement and $17-\beta$ estradiol were from Sigma-Aldrich (Deisenhofen, Germany). ER $\beta$ agonists ERB-041 and WAY-200070 were from Tocris (Bristol, UK). $5 \alpha$-androstane-3 $\beta$, $17 \beta$ diol (3 $\beta$-Adiol) was from Sigma (Deisenhofen, Germany) and Liquiritigenin from Extrasynthese (Lyon, France).

\section{Cell culture, transfection and proliferation assays}

OVCAR-3 and OAW-42 cells were maintained in DMEM/ F12 medium supplemented with $10 \%$ FCS at $37^{\circ} \mathrm{C}$ in a humidified atmosphere containing $5 \% \mathrm{CO}_{2}$. For transfection, $4 \times 10^{5}$ cells per well of a 6 -well dish were seeded in DMEM/F12 containing 10\% FCS. The next day, $2 \mathrm{ml}$ fresh culture medium was added to the cells. $5 \mu \mathrm{l}$ Transfectin reagent (BioRad) and a mix of three ESR2 siRNAs (10 nM each) were used to prepare transfection solution in OptiMEM medium (Invitrogen). The siRNA mix contained three different ESR2-specific Silencer siRNAs (siRNA IDs 145,909, 145,910, 145,911, Ambion), targeting exons 1, 2 and 3 of ESR2 mRNA. As a negative control, Silencer Negative control siRNA \#1 (Ambion) was used. Gene knockdown of ESR2 was verified by means of Western blot analysis $72 \mathrm{~h}$ after siRNA treatment as described below. For cell proliferation assays, cells cultured in DMEM/F12 supplemented with $10 \%$ FBS or serum replacement 2, both containing $0.1 \mathrm{nM} \mathrm{E2}$, were seeded in 96-well plates in triplicates (1000 cell/well). For agonist analyses, ER $\beta$ agonists were added in a $10 \mathrm{nM}$ concentration 1day later. The relative numbers of viable cells were measured on days $0,3,4$, 5, 6 and 7 using the fluorimetric, resazurin-based Cell Titer Blue assay (Promega) according to the manufacturer's instructions at $560 \mathrm{Ex} / 590 \mathrm{Em} \mathrm{nm}$ in a Victor3 multilabel counter (PerkinElmer, Germany). Cell growth was expressed as percentage of cells transfected with negative control siRNA. Growth data were statistically analyzed by the Kruskal-Wallis one-way analysis of variance.

\section{Antibodies and Western blot analysis}

OAW-42 and OVCAR-3 cells were lysed in RIPA buffer $(1 \%(v / v)$ Igepal CA-630, 0.5\% $(w / v)$ sodium deoxycholate, $0.1 \%(w / v)$ sodium dodecyl sulphate (SDS) in phosphate-buffered solution (PBS) containing aprotinin and sodium orthovanadate. Aliquots containing $10 \mu \mathrm{g}$ of 
protein were resolved by $10 \%(w / v)$ SDS-polyacrylamide gel electrophoresis, followed by electrotransfer to a PVDF hybond (Amersham, UK) membrane. Immunodetection was carried out using monoclonal ER $\beta$ (ESR2) antibody 14C8 (ab288, Abcam, Germany), diluted 1:100 in PBS containing 5\% skim milk $(w / v)$, ER $\alpha$ (ESR1) antibody 6F11 (ab9269, Abcam, Germany) (1:500), lipocalin1 (LCN1) antibody STJ96584 by St John's Laboratory (London, UK) (1:300), Patched 2 (PTCH2) antibody ABIN1673339 (1: 500) by antibodies-online (Aachen, Germany), Mitochondrially Encoded NADH Dehydrogenase 6 (MT-ND6) antibody ABIN311275 (1:1000) by antibodies-online (Aachen, Germany), $\beta$-actin (ACTB) antibody (clone AC-74) from Sigma Aldrich (Munich, Germany) followed by horseradish peroxidase conjugated secondary antibody $(1: 50,000)$ which was detected using chemiluminescence (ECL) system (Amersham, Buckinghamshire, UK). The Western blot results from three independent protein isolations were densitometrically analyzed using ImageJ [22] and expressed in percentage of cell treated with a vehicle control.

\section{GeneChip ${ }^{\mathrm{TM}}$ microarray assay}

Processing of the RNA samples (two biological replicates from OVCAR-3 and OAW-42 cells treated with E2 $(0.1 \mathrm{nM})$ in combination with ER $\beta$ agonists $(10 \mathrm{nM})$ or vehicle controls for $48 \mathrm{~h}$ ) was performed at the local Affymetrix Service Provider and Genomics Core Facility, "KFB - Centre of Excellence for Fluorescent Bioanalytics" (Regensburg, Germany; www.kfb-regensburg.de).

Samples were prepared for microarray hybridization as described in the Affymetrix GeneChip Whole Transcript (WT) Sense Target Labelling Assay manual. Doublestranded cDNA was generated from $300 \mathrm{ng}$ of total RNA. Subsequently, cRNA was synthesized using the WT cDNA Synthesis and Amplification Kit (Affymetrix). cRNA was purified and reverse transcribed into singlestranded (ss) DNA. Subsequently a combination of uracil DNA glycosylase (UDG) and apurinic/apyrimidinic endonuclease 1 (APE 1) was used to fragment ssDNA, which was afterwards labelled with biotin (WT Terminal Labelling Kit, Affymetrix). In a rotating chamber, $2.3 \mu \mathrm{g}$ DNA were hybridized to the GeneChip Human Gene 1.0 ST Array (Affymetrix) for $16 \mathrm{~h}$ at $45^{\circ} \mathrm{C}$. After washing and staining the hybridized arrays in an Affymetrix Washing Station FS450 using preformulated solutions (Hyb, Wash \& Stain Kit, Affymetrix), the fluorescent signals were measured with an Affymetrix GeneChip Scanner 3000-7G.

\section{Microarray data analysis}

Summarized probe signals were created by using the RMA algorithm in the Affymetrix GeneChip Expression Console Software and exported into Microsoft Excel.
Data was then analysed using Ingenuity IPA Software (Ingenuity Systems, Stanford, USA) and Genomatix Pathway Analysis software (Genomatix, Munich, Germany). Genes with more than 2-fold changed mRNA levels after ER $\beta$ knockdown in both biological replicates were considered to be differentially expressed and were included in the analyses.

\section{Results}

Expression of ERa and $\beta$ in OVCAR-3 and OAW-42 cells First, we tested expression of ER $\alpha$ and $E R \beta$ in the employed ovarian cancer cell lines OVCAR-3 and OAW-42. Western blot experiments demonstrated that both cell lines expressed ER $\beta$ protein at similar levels, whereas ER $\alpha$ protein levels were about 4-fold higher in OVCAR-3 cells (Fig. 1).

\section{ER $\beta$ agonists decreased proliferation of OVCAR- 3 and OAW-42 cells}

OVCAR3 and OAW-42 cells were treated with four different ER $\beta$ agonists, ERB-041, WAY-200070, Liquiritigenin and 3 $\beta$-Adiol. Culture medium contained either $10 \%$ FCS or defined growth factor-free serum replacement, both containing E2 $(0.1 \mathrm{nM})$. After treatment of OVCAR-3 and OAW- 42 cells with the ER $\beta$ agonists, all of these drugs were observed to significantly decrease proliferation in both cell lines at a concentration of $10 \mathrm{nM}$. We decided to test this concentration only, because the EC50 values for ER $\beta$ binding of all drugs are in the low nanomolar range, and we wanted to rule out activation of ER $\alpha$ by higher drug concentrations, which could be able to increase proliferation.

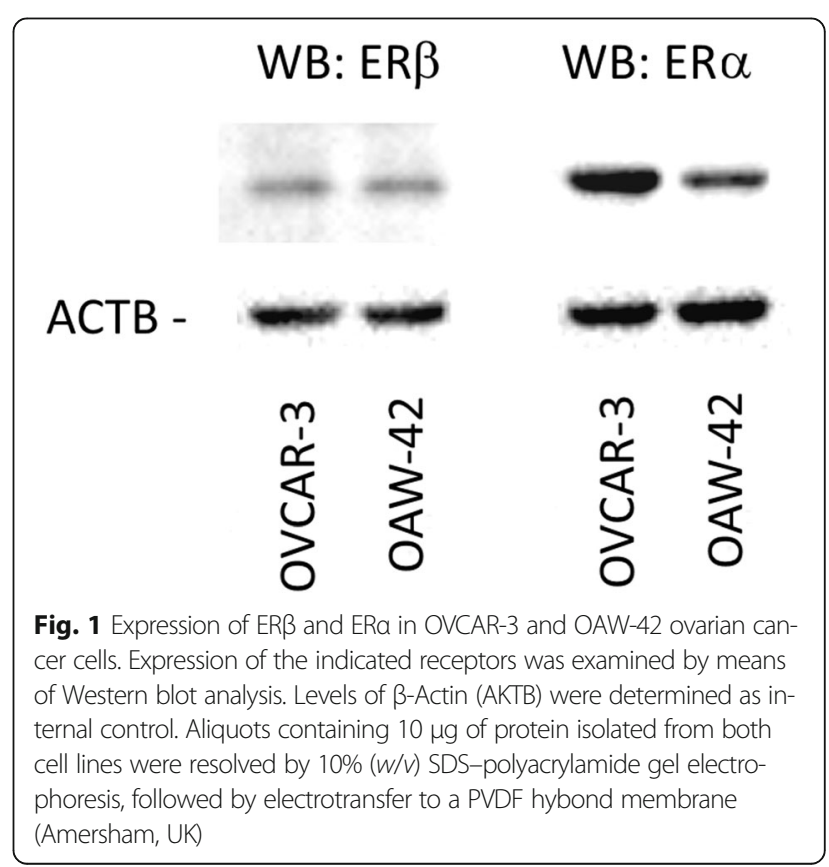


In OVCAR-3 cells, maximum growth-inhibitory effects were induced by Liquiritigenin, which decreased the number of viable cells down to $68.8 \%$ after 5 days of treatment in medium supplemented with 10\% FCS, when compared to cells treated with vehicle (Fig. 2). In SR2 containing medium, Liquiritigenin reduced viable cell numbers down to $78.6 \%$ on day 7 . Treatment of OVCAR-3 cells with ERB-041 decreased the number of viable cells to $70.9 \%$ (day 5) in FCS containing medium and down to $78.6 \%$ (day 7) when cultured with defined serum replacement. WAY200070 treatment of OVCAR3 cells inhibited proliferation to $78.1 \%$ on day 5 in FCS containing medium $(79.3 \%$ on day 7 in SR2 containing medium). When 3 $\beta$-Adiol was added, maximum effects were observed on day 3 with a decrease of viable cells down to $79.6 \%$ or $83.8 \%$ in FCS or SR2 containing medium, respectively.

All ER $\beta$ agonists tested also exerted significant growth inhibitory effects on OAW-42 cells. In contrast to OVCAR-3 cells, these effects were more pronounced in defined serum-free medium (Fig. 2). Maximum antiproliferative effects were observed in OAW-42 cells treated with WAY200070 on day 6 , with a decrease of viable cell numbers to $73.2 \%$ in SR2 containing medium (81.8\% on day 4 in FCS containing medium). Treatment with ERB041 led to a maximum reduction of viable cells on day 3 down to $75.6 \%$ in SR2 and $81.3 \%$ in FCS containing medium. When OAW-42 cells were treated with Liquiritigenin, we observed a reduction of viable cell numbers down to $76.8 \%$ on day 4 (in FCS; $83.1 \%$ in SR2 on day $5)$. After treatment with $3 \beta$-Adiol, a maximum antiproliferative effect was observed on day 6 when cells were cultured in defined serum replacement (reduction of viable cells to $80.4 \%$ ), whereas cell numbers were decreased to $80.9 \%$ on day 4 when cultured in FCS.

\section{Increased proliferation of OAW-42 cells after knockdown of ER $\beta$}

After having shown a decrease of ovarian cancer cell proliferation resulting from treatment with ER $\beta$ agonists, we examined, whether knockdown of ER $\beta$ would have the opposite effect. In OAW-42 cells, $72 \mathrm{~h}$ after transfection with ESR2 siRNA, Western blot analysis revealed maximum suppression of ER $\beta$ protein levels down to $10,5 \%(p<0.01)$ (Fig 3a). In OVCAR-3 cells, siRNA treatment resulted in a knockdown of ER $\beta$ by $65.7 \%$ only, although different transfection parameters were tested (data not shown). Since this knockdown was not sufficient, we had to continue with OAW-42 cells only. When OAW-42 cells were seeded $48 \mathrm{~h}$ after siRNA transfection for assessment of proliferation, we observed a significant increased growth rate of cells transfected with ESR2 siRNA compared to negative control siRNA. This effect was present from day 4 until day 6 of the

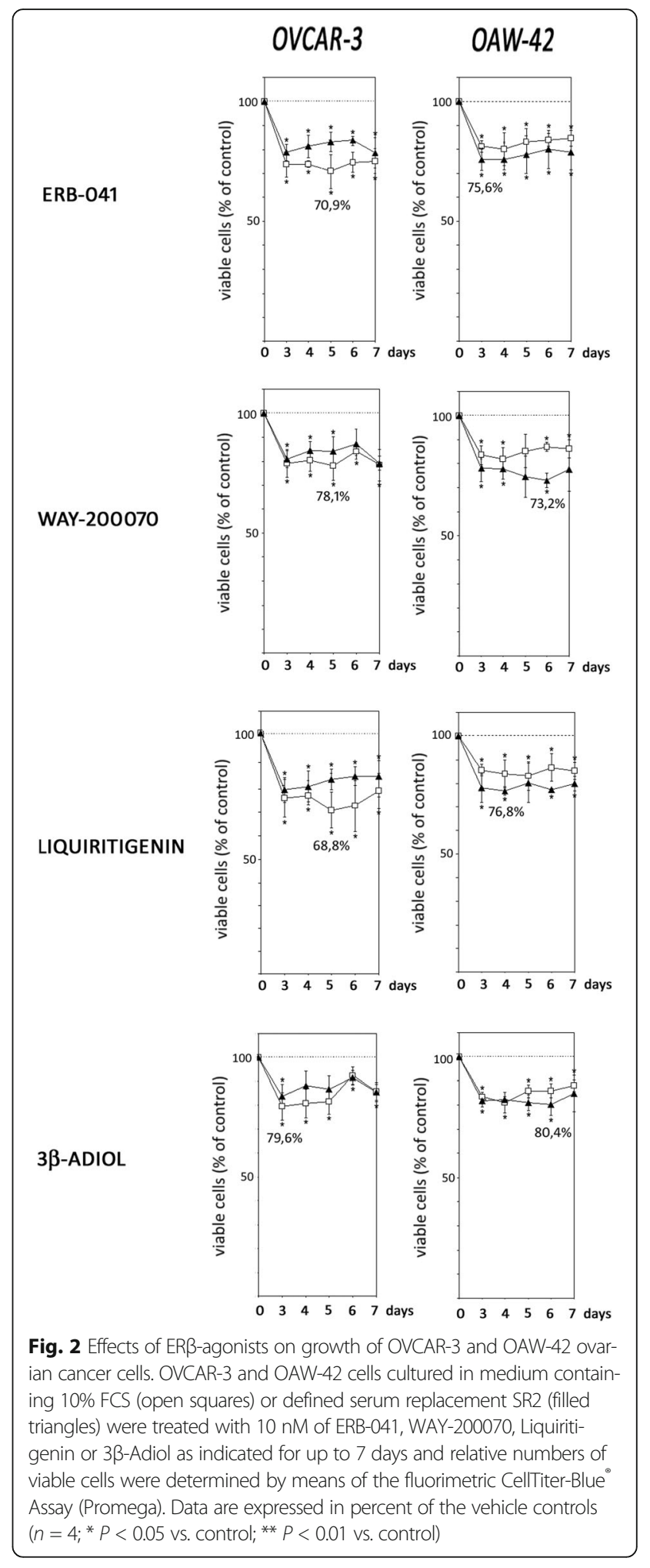

proliferation assay, with a maximum effect of ESR2 siRNA on day 4 , resulting in a 1.9-fold increase of viable cells $(p<0.01)$ (Fig. 3b). 


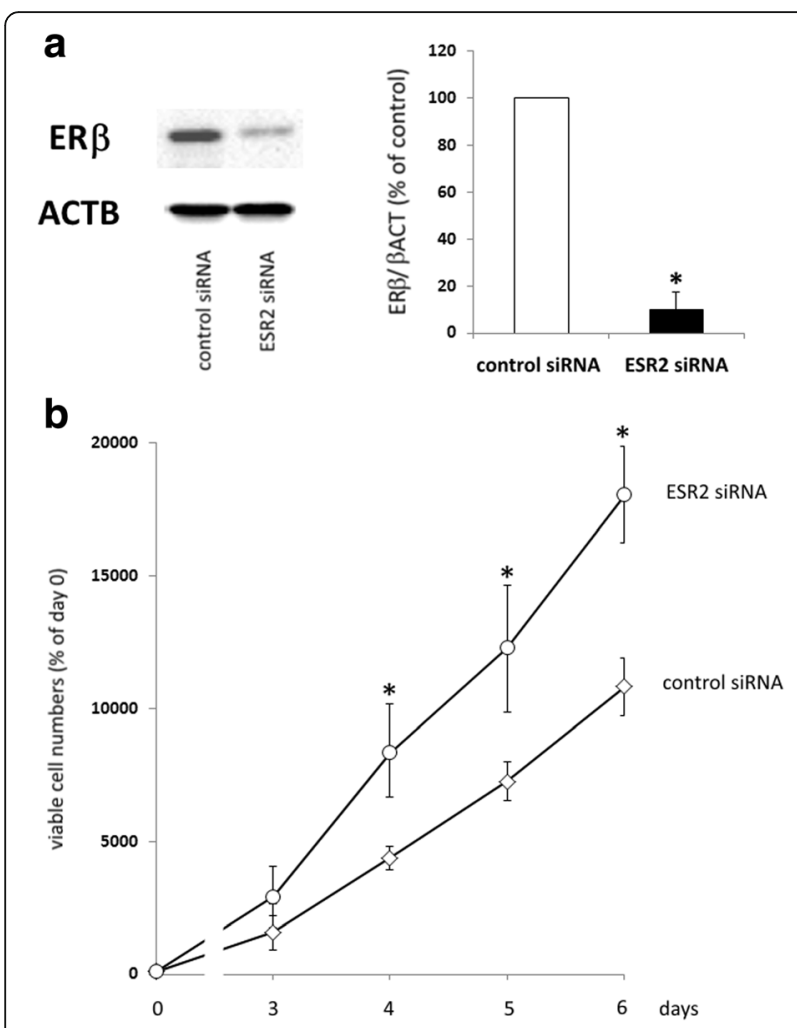

Fig. 3 Effect of an ER $\beta$ knockdown on proliferation of OAW-42 cells. a: ERB expression in OAW-42 ovarian cancer cells after transfection with ER $\beta$ siRNA compared to controls. $72 \mathrm{~h}$ after transfection, total protein was isolated and knockdown was examined on the protein level by means of Western blot analysis as described in the methods section. ER $\beta$ expression levels after transfection with a mix of ESR2 siRNAs (10 nM each) were compared to levels in cells transfected with negative control siRNA $(n=4)$. ${ }^{*} p<0.01$ vs. control-transfected cells. $\mathbf{b}$ : Proliferation of OAW-42 cells with reduced levels of ERB. Cells were transfected with ESR2-specific siRNA or negative control siRNA and seeded into 96-well plates (1000 cells/well) in medium containing 10\% FCS the next day. 0, 3, 4,5 , and 6 days after transfection, relative numbers of viable cells were determined by means of the fluorimetric CellTiter-Blue Assay (Promega). From one vial of transfected cells, $72 \mathrm{~h}$ after transfection total RNA and protein was isolated in parallel to confirm knockdown of ESR2 expression. Data are expressed in percent of day $0(n=4) .{ }^{*} p<0.01 \mathrm{vs}$. control-transfected cells

\section{Drug effects on the transcriptome of OVCAR-3 and OAW- 42 cells}

To analyze the molecular mechanisms underlying the antiproliferative effect of ER $\beta$ agonists, we employed Affymetrix Human GeneChips 1.0 to analyze the effect of ERB-041, Liquiritigenin and WAY200070 on transcriptome of both cell lines. While changes of the transcriptome were smaller than expected, cell line OAW-42 was found to be more sensitive to treatment with ER $\beta$ agonists in terms of gene expression changes than OVCAR-3 cells. Whereas in OAW-42 cells 3 genes were induced and 9 were downregulated more than 2-fold by at least one of the drugs, in OVCAR-3 cells transcript levels of only 3 genes were found to be decreased more than 2-fold. Among the upregulated genes, C6ORF99 and TPTE2 were more than 2-fold increased in OAW42 cells by two different ER $\beta$ agonists (Table 1 ). In OVCAR-3 cells, expression of the genes LCN1 and C21ORF94 was more than 2-fold decreased after treatment with ERB-041 and Liquiritigenin. LCN1 gene was also found to be downregulated by ERB-041 in OAW-42 cells. In the latter line, other significantly downregulated genes were PTCH2, SNORD25, ND6 and SNORD1.

To confirm the results of DNA microarray analysis on the protein level, we performed Western blot experiments to study the effects of ER $\beta$ agonists on protein expression of four of those genes most considerably regulated on the mRNA level. In these experiments, we observed strong down-regulation of $\mathrm{PTCH} 2$ protein by WAY200070 down to $18.7 \%$ in OAW-42 cells $(p<0.01)$, decrease of LCN1 by agonist ER $\beta-041$ down to $21.3 \%$ in OVCAR-3 cells $(p<0.01)$. ND6 protein levels in OAW42 cells decreased down to $13.9 \%$ after treatment with ER $\beta-041(p<0.01)$, to $25,5 \%$ by Liquiritigenin $(p<0.01)$ and to $15.4 \%$ by WAY200070 ( $p<0.01)$ (Fig. 4$)$. In contrast, we did not observe a significant effect of the ER $\beta$ agonists tested on protein expression of EpCAM which was suggested by microarray results (data not shown).

DNA Microarray analyses also revealed agonisttriggered regulation of two growth-associated genes which might be an underlying mechanism of the observed growth inhibition. Cyclin E2 (CCNE2) expression was found to be decreased after treatment with ER $\beta$ agonist Liquiritigenin by $38.6 \%$ in OVCAR-3 cells and by $32.8 \%$ after treatment with WAY200070 in the same cell line (both $p<0.05$ ). In OAW-42 cells, the latter agonist reduced cyclin E2 expression by $35.1 \%$ $(p<0,05)$. In contrast, expression of growth arrest specific 2 (GAS2) gene was elevated after treatment with ER $\beta$ agonists ERB-041 and WAY200070 in OAW-42 cells (by $42.5 \%$ or $37.0 \%$, respectively, $p<0.05$ ), and in OVCAR-3 cells by $31.6 \%$ after treatment with Liquiritigenin (Fig. 5a).

\section{Pathway analysis}

Analysis of the transcriptome changes triggered by ER $\beta$ agonists using Ingenuity Pathway Analysis software (IPA, Ingenuity Systems) revealed an estrogendependent network consisting of the downregulated genes LCN1, EpCAM, PTCH2 and ND6 (Fig. 5b).

\section{Discussion}

In this study, for the first time we report significant inhibitory effects of ER $\beta$ agonists on growth of ovarian cancer cell lines. In turn we demonstrated a significant proliferation increase after siRNA-mediated knockdown of ER $\beta$, corroborating both our agonist findings and the 
Table 1 Genes regulated after treatment of the indicated ovarian cancer cell lines with the specific ER $\beta$ agonists ERB-041, Liquiritigenin (LIQ.) and WAY - 2,000,070 for $48 \mathrm{~h}$. Shown are genes with at least 2-fold regulation in one experimental setting (values in italics). Data were assessed by means of Affymetrix GeneChip 1.0 microarray analyses and are expressed in -fold change compared to the vehicle control

\begin{tabular}{|c|c|c|c|c|c|c|}
\hline & \multicolumn{3}{|l|}{ OAW-42 } & \multicolumn{3}{|l|}{ OVCAR-3 } \\
\hline & ERB-041 & LIQ. & WAY200070 & ERB-041 & LIQ. & WAY20007C \\
\hline \multicolumn{7}{|c|}{ Up-regulated genes } \\
\hline C6ORF99 & 2,52 & 3,81 & 1,91 & 1,35 & 1,01 & $-1,17$ \\
\hline TPTE2 & 1,67 & 2,05 & 2,26 & 1,05 & 1,22 & 1,08 \\
\hline CD177 & 1,55 & $-1,08$ & 2,14 & 1,53 & 1,62 & 1,79 \\
\hline \multicolumn{7}{|c|}{ Down-regulated genes } \\
\hline LINC00314 & 1,24 & $-1,26$ & $-1,44$ & $-1,86$ & $-2,09$ & $-2,71$ \\
\hline EPCAM & $-1,35$ & $-1,41$ & $-2,20$ & $-1,21$ & $-1,02$ & $-1,05$ \\
\hline SNORD25 & $-2,07$ & $-1,07$ & $-2,00$ & $-1,03$ & $-1,11$ & $-1,07$ \\
\hline RNU4-2 & $-1,46$ & $-2,09$ & $-1,49$ & $-1,16$ & $-1,21$ & $-1,03$ \\
\hline RNU2-1 & $-1,62$ & $-1,57$ & $-2,05$ & $-1,29$ & $-1,03$ & $-1,30$ \\
\hline PTCH2 & $-1,67$ & $-1,76$ & $-2,08$ & $-1,37$ & $-1,10$ & $-1,33$ \\
\hline RNU5B-1 & $-1,51$ & $-1,79$ & $-2,54$ & $-1,11$ & $-1,23$ & $-1,09$ \\
\hline ND6 & $-2,11$ & $-2,12$ & $-4,01$ & $-1,38$ & $-1,11$ & 1,42 \\
\hline FAM48B2 & $-1,29$ & $-1,30$ & $-1,73$ & $-2,11$ & $-1,72$ & $-1,76$ \\
\hline LCN1 & $-2,28$ & $-1,12$ & $-1,11$ & -2.14 & $-2,38$ & $-1,61$ \\
\hline SNORA1 & $-1,82$ & $-2,07$ & $-2,09$ & $-1,39$ & $-1,41$ & $-1,71$ \\
\hline
\end{tabular}

suggested tumor suppressor role of this receptor in ovarian cancer. Though all ER $\beta$ agonists inhibited ovarian cancer cell growth, their effect on gene expression partially differed due to their known structural differences.

In ovarian cancer, steroid hormone receptors ER $\alpha$ and $\beta$ are commonly expressed. Especially in normal ovarian tissue ER $\beta$ shows high expression levels, which decrease during carcinogenesis $[3,14,15,23-26]$. This loss of ER $\beta$ could be an important step for the development of ovarian cancer and might even be a general mechanism during tumorigenesis of estrogen-dependent tissues. A number of in vitro studies, including one from our group, support the tumor-suppressive role of ER $\beta$ in ovaries [20, 27-33].

The results of our knockdown experiments, clearly suggesting an antiproliferative effect of ER $\beta$ in ovarian cancer cells, are in line with previous studies by us and others, reporting growth inhibition after overexpression of $\operatorname{ER} \beta$ or growth increase after knockdown of this receptor $[17,20]$.

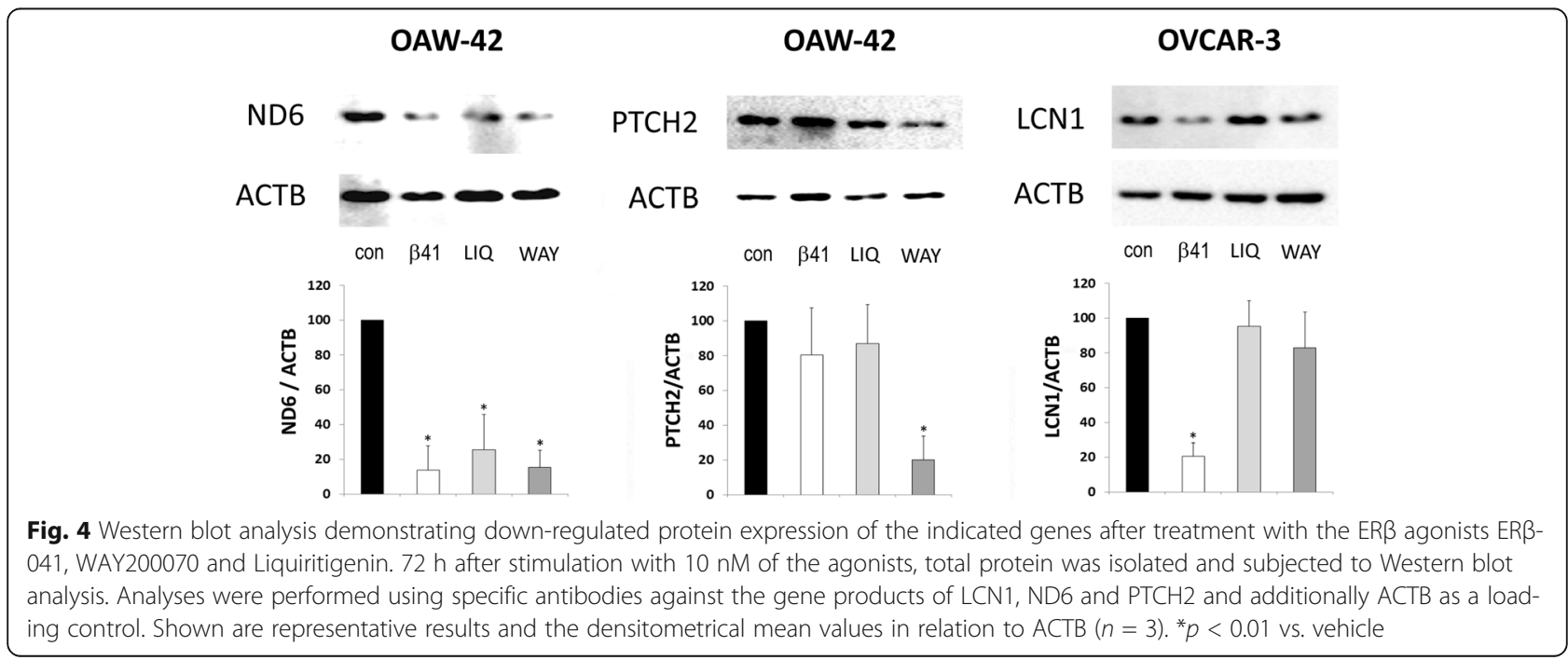



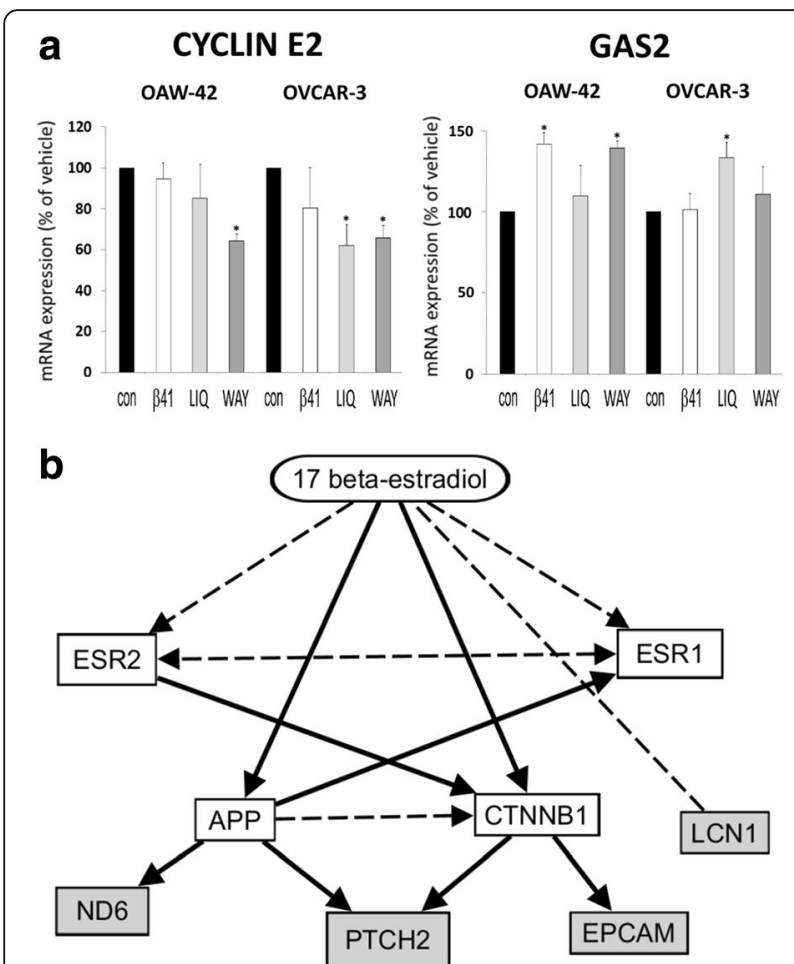

Fig. 5 Effect of ERß agonists on gene expression (Affymetrix GeneChip analysis). a Regulation of growth-associated genes cyclin E2 and growth arrest specific 2 (GAS2) after treatment with the agonists ERB-041 ( $\beta 41)$, Liquiritigenin (LIQ), WAY200070 (WAY) or the vehicle control (con) for $48 \mathrm{~h}(10 \mathrm{nM}){ }^{*} p<0.05$ bs. Vehicle. $\mathbf{b}$ Network connecting ESR2 with the genes LCN1, EPCAM, PTCH2 and ND6 being downregulated by ER $\beta$ agonists in this study. Broken lines: direct binding. Solid lines: affecting expression. Prediction by IPA Software (Ingenuity Pathway Analysis, Ingenuity Systems, Stanford, USA) [54-61]

In our study we addressed the question, whether expression of ER $\beta$ in ovarian cancer cells still might be high enough to make this receptor a potential target in ovarian cancer therapy. Thus, we investigated how ovarian cancer cells responded to treatment with ER $\beta$ agonists, which have been reported to bind preferentially to this receptor, but only to a much smaller extent to ER $\alpha$. $3 \beta$-Adiol ( $5 \alpha$-androstane- $3 \beta, 17 \beta$-diol) is a dihydrotestosterone metabolite which does not bind androgen receptors. However, it efficiently binds ER $\beta$ [34] and acts as a physiological ER $\beta$-activator in different tissues [35, 36]. ERB-041 and WAY-200070 are highly specific synthetic ER $\beta$ agonists $[37,38]$. ERB-041 is known to display a more than 200 -fold selectivity for $E R \beta$ than for $E R \alpha\left(E C_{50} E R \beta=2 \mathrm{nM}\right)$, WAY-200070 still has a 68-fold higher selectivity for $E R \beta$ than for $E R \alpha\left(E C_{50} E R \beta=2 n M\right.$ [39]). Liquiritigenin is a plant-derived flavonoid from licorice root, which acts as a highly selective agonist of $\operatorname{ER} \beta\left(E_{50} \operatorname{ER} \beta=36.5 \mathrm{nM}[40]\right)$. Recently, we have

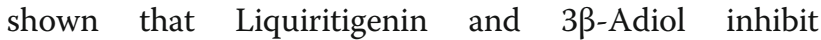

proliferation of different breast cancer cell lines. However, proliferation of ER $\alpha$-positive breast cancer cell lines was not affected by the agonists WAY200070 and ERB$041[41,42]$. We decided to use a $10 \mathrm{nM}$ concentration of the agonists only, because the EC50 values for ER $\beta$ binding of all drugs are in the low nanomolar range, and possible ER $\beta$-unspecific effects of higher drug concentrations on proliferation e.g. via ER $\alpha$ activation thus could be ruled out. Though all agonists affected proliferation regardless of the serum supplement used, our observation that agonist effects in the presence of $10 \%$ FCS were higher on OVCAR-3, but lower in OAW-42 cells compared to defined growth-factor free serum replacement might be explained by the different mutation status of these cell lines. OAW- 42 cells derive from ascites from a serous ovarian cancer, they obtain mutations of BRCA1 and PIK3CA, but not of $p 53$ [43]. OVCAR-3 cells were attained from ascites of a patient with highgrade serous ovarian cancer (G3) and exhibit a mutation of $p 53$ [43]. Thus, proliferation of OVCAR-3 cells, which is elevated due to mutated p53 and is further increased by growth factors, might be more sensitive to growth inhibition by ER $\beta$ agonists [44].

The transcriptome analyses of both cell lines we performed after treatment with ER $\beta$ agonists ERB-041, Liquiritigenin and WAY-200070 revealed possible molecular mechanisms underlying the observed antiproliferative effects. In our study we observed downregulation of $P T C H 2$ in OAW- 42 cells both on the mRNA and protein level after treatment with ER $\beta$ agonist WAY200070. PTCH2 gene encodes a transmembrane receptor and is part of the hedgehog signaling pathway, which is known to play an important role in the development of several malignancies [45-49]. High expression of PTCH2 was associated with a poorer survival in patients with bladder cancer [47]. Recently, Worley et al. showed a significant overexpression of PTCH2 in ovarian clear cell carcinoma and associated endometriosis [50]. Given that knockdown of PTCH2 was reported to exert significant growth inhibition in a clear cell cancer cell line, this gene might be in part responsible for the observed growth inhibitory effects of this ER $\beta$ agonist [50].

Pathway analysis suggested that the observed effects of ER $\beta$ agonists are mediated by $\beta$-catenin (CTNNB1) and amyloid $\beta$ precursor protein (APP), which have been reported to form a complex [51]. Expression of APP and CTNNB1 previously has been reported to be inducible by estrogens [52, 53]. CTNNB1 activity has been reported to be inhibited by ESR2 and is known to affect expression of EpCAM and $P T C H 2$, which could explain the link between ER $\beta$ agonists and decreased expression of PTCH2 and EpCAM we observed in OAW-42 cells [54-56]. The fact that estrogen-inducible APP has been 
reported to increase expression of ND6 and $\mathrm{PTCH} 2$ provides a putative molecular mechanism between ESR2 knockdown and the observed downregulation of ND6 and PTCH2 $[57,58]$.

Our observation of $L C N 1$ downregulation particularly by ERB-041 in both cell lines could be explained by the fact that E2 has been reported to regulate $L C N 1$ gene expression [59,60]. The role of this transporter of small lipophilic ligands in cancer is unclear. However, it remains to be investigated whether LCN1 might exert tumor-promoting functions like its family member LCN2 known to induce epithelial to mesenchymal transition and to promote breast cancer invasion in an ER $\alpha$ dependent manner $[61,62]$.

\section{Conclusions}

In this study, we were able to demonstrate a significant decrease of proliferation of two ovarian cancer cell lines triggered by different ER $\beta$ agonists. Microarray analyses revealed a set of cancer-associated genes being regulated by these agonists. This and the observed increase of proliferation after ER $\beta$ knockdown suggest an important role of this receptor in growth control of ovarian cancer cells. Our data suggest, that ER $\beta$ could be a promising target for therapy of ovarian cancer. To what extent ER $\beta$ agonists could be suitable in the clinical setting has to be examined in further studies.

\section{Abbreviations}

DMEM: Dulbecco's modified eagle's medium; DNA: Deoxyribonucleic acid; ERR: Estrogen receptor beta; FCS: Fetal calf serum; RNA: Ribonucleic acid; siRNA: Short interfering ribonucleic acid

\section{Acknowledgements}

Not applicable.

\section{Funding}

No funding.

\section{Availability of data and material}

The datasets supporting the conclusions of this article are included in the article and its additional files.

\section{Authors' contributions}

SST made substantial contributions to conception and design, acquisition of data analysis and interpretation of data. CM made substantial contributions to acquisition of data. MS has been involved in revising the manuscript critically for important intellectual content. OO has been involved in revising the manuscript critically for important intellectual content. OT made substantial contributions to conception and design, acquisition of data analysis and interpretation of data. All authors read and approved the final manuscript.

\section{Competing interests}

The authors declare that they have no competing interests.

\section{Consent for publication}

Not applicable.

Ethics approval and consent to participate Not applicable.

\section{Publisher's note}

Springer Nature remains neutral with regard to jurisdictional claims in published maps and institutional affiliations.

\section{Author details}

${ }^{1}$ Department of Obstetrics and Gynecology, University Medical Center Regensburg, Landshuter Str. 65, 93053 Regensburg, Germany. ${ }^{2}$ Center of Excellence for Fluorescent Bioanalytics (KFB), Am BioPark 9, 93053 Regensburg, Germany. ${ }^{3}$ Second Department of Gynecology, Medical University of Lublin, Jaczewskiego 8, 20-090 Lublin, PL, Poland.

Received: 11 October 2016 Accepted: 30 March 2017

Published online: 08 May 2017

\section{References}

1. Siegel RL, Miller KD, Jemal A. Cancer statistics, 2015. CA Cancer J Clin. 2015; 65(1):5-29.

2. Aikhionbare FO, Mehrabi S, Kumaresan K, Zavareh M, Olatinwo M, Odunsi K, Partridge E. Mitochondrial DNA sequence variants in epithelial ovarian tumor subtypes and stages. J Carcinog. 2007;6:1.

3. Docquier A, Garcia A, Savatier J, Boulahtouf A, Bonnet S, Bellet V, Busson M, Margeat $E$, Jalaguier $S$, Royer $C$, et al. Negative regulation of estrogen signaling by ERbeta and RIP140 in ovarian cancer cells. Mol Endocrinol. 2013;27(9):1429-41.

4. Greenlee RT, Murray T, Bolden S, Wingo PA. Cancer statistics, 2000. CA Cancer J Clin. 2000:50(1):7-33.

5. Havrilesky LJ, McMahon CP, Lobenhofer EK, Whitaker R, Marks JR, Berchuck A. Relationship between expression of coactivators and corepressors of hormone receptors and resistance of ovarian cancers to growth regulation by steroid hormones. J Soc Gynecol Investig. 2001;8(2):104-13.

6. Yokoyama $Y$, Mizunuma H. Recurrent epithelial ovarian cancer and hormone therapy. World J Clin Cases. 2013;1(6):187-90.

7. Hatch KD, Beecham JB, Blessing JA, Creasman WT. Responsiveness of patients with advanced ovarian carcinoma to tamoxifen. A gynecologic oncology group study of second-line therapy in 105 patients. Cancer. 1991;68(2):269-71.

8. Scambia G, Benedetti-Panici P, Ferrandina G, Distefano M, Salerno G, Romanini ME, Fagotti A, Mancuso S. Epidermal growth factor, oestrogen and progesterone receptor expression in primary ovarian cancer: correlation with clinical outcome and response to chemotherapy. Br J Cancer. 1995;72(2):361-6.

9. Beral V, Gaitskell K, Hermon C, Moser K, Reeves G, Peto R. Menopausal hormone use and ovarian cancer risk: individual participant meta-analysis of 52 epidemiological studies. Lancet. 2015;385(9980):1835-42.

10. Merchenthaler I, Shugrue PJ. Estrogen receptor-beta: a novel mediator of estrogen action in brain and reproductive tissues. Morphological considerations. J Endocrinol Invest. 1999;22(10 Suppl):10-2.

11. Couse JF, Curtis Hewitt S, Korach KS. Receptor null mice reveal contrasting roles for estrogen receptor alpha and beta in reproductive tissues. J Steroid Biochem Mol Biol. 2000;74(5):287-96.

12. Lindberg MK, Moverare S, Skrtic S, Gao H, Dahlman-Wright K, Gustafsson JA, Ohlsson C. Estrogen receptor (ER)-beta reduces ERalpha-regulated gene transcription, supporting a "ying yang" relationship between ERalpha and ERbeta in mice. Mol Endocrinol. 2003;17(2):203-8.

13. Cheng J, Lee EJ, Madison LD, Lazennec G. Expression of estrogen receptor beta in prostate carcinoma cells inhibits invasion and proliferation and triggers apoptosis. FEBS Lett. 2004:566(1-3):169-72.

14. Pujol P, Rey JM, Nirde P, Roger P, Gastaldi M, Laffargue F, Rochefort $H$, Maudelonde T. Differential expression of estrogen receptor-alpha and -beta messenger RNAs as a potential marker of ovarian carcinogenesis. Cancer Res. 1998:58(23):5367-73.

15. Rutherford T, Brown WD, Sapi E, Aschkenazi S, Munoz A, Mor G. Absence of estrogen receptor-beta expression in metastatic ovarian cancer. Obstet Gynecol. 2000;96(3):417-21

16. Bardin A, Boulle N, Lazennec G, Vignon F, Pujol P. Loss of ERbeta expression as a common step in estrogen-dependent tumor progression. Endocr Relat Cancer. 2004;11(3):537-51.

17. Bossard C, Busson M, Vindrieux D, Gaudin F, Machelon V, Brigitte M, Jacquard C, Pillon A, Balaguer P, Balabanian K, et al. Potential role of estrogen receptor beta as a tumor suppressor of epithelial ovarian cancer. PLoS One. 2012;7(9):e44787.

18. Fekete T, Raso E, Pete I, Tegze B, Liko I, Munkacsy G, Sipos N, Rigo Jr J, Gyorffy B. Meta-analysis of gene expression profiles associated with 
histological classification and survival in 829 ovarian cancer samples. Int J Cancer. 2012;131(1):95-105.

19. Lazennec G, Bresson D, Lucas A, Chauveau C, Vignon F. ER beta inhibits proliferation and invasion of breast cancer cells. Endocrinology. 2001;142(9):4120-30.

20. Treeck O, Pfeiler G, Mitter D, Lattrich C, Piendl G, Ortmann O. Estrogen receptor $\{$ beta\}1 exerts antitumoral effects on SK-OV-3 ovarian cancer cells. J Endocrinol. 2007;193(3):421-33.

21. Kyriakidis I, Papaioannidou P. Estrogen receptor beta and ovarian cancer: a key to pathogenesis and response to therapy. Arch Gynecol Obstet. 2016; 293(6):1161-8

22. Schneider CA, Rasband WS, Eliceiri KW. NIH image to ImageJ: 25 years of image analysis. Nat Methods. 2012;9(7):671-5.

23. Brandenberger AW, Tee MK, Jaffe RB. Estrogen receptor alpha (ER-alpha) and beta (ER-beta) mRNAs in normal ovary, ovarian serous cystadenocarcinoma and ovarian cancer cell lines: down-regulation of ERbeta in neoplastic tissues. J Clin Endocrinol Metab. 1998;83(3):1025-8.

24. Chan KK, Wei N, Liu SS, Xiao-Yun L, Cheung AN, Ngan HY. Estrogen receptor subtypes in ovarian cancer: a clinical correlation. Obstet Gynecol. 2008; 111(1):144-51.

25. De Stefano I, Zannoni GF, Prisco MG, Fagotti A, Tortorella L, Vizzielli G, Mencaglia L, Scambia G, Gallo D. Cytoplasmic expression of estrogen receptor beta (ERbeta) predicts poor clinical outcome in advanced serous ovarian cancer. Gynecol Oncol. 2011;122(3):573-9.

26. Suzuki F, Akahira J, Miura I, Suzuki T, Ito K, Hayashi S, Sasano H, Yaegashi N. Loss of estrogen receptor beta isoform expression and its correlation with aberrant DNA methylation of the $5^{\prime}$-untranslated region in human epithelial ovarian carcinoma. Cancer Sci. 2008;99(12):2365-72.

27. Paruthiyil S, Parmar H, Kerekatte V, Cunha GR, Firestone GL, Leitman DC. Estrogen receptor beta inhibits human breast cancer cell proliferation and tumor formation by causing a G2 cell cycle arrest. Cancer Res. 2004;64(1):423-8.

28. Strom A, Hartman J, Foster JS, Kietz S, Wimalasena J, Gustafsson JA. Estrogen receptor beta inhibits 17 beta-estradiol-stimulated proliferation of the breast cancer cell line T47D. Proc Natl Acad Sci U S A. 2004;101(6):1566-71.

29. Zhu J, Hua K, Sun H, Yu Y, Jin H, Feng Y. Re-expression of estrogen receptor beta inhibits the proliferation and migration of ovarian clear cell adenocarcinoma cells. Oncol Rep. 2011;26(6):1497-503.

30. Lazennec G. Estrogen receptor beta, a possible tumor suppressor involved in ovarian carcinogenesis. Cancer Lett. 2006;231(2):151-7.

31. Liu MM, Albanese C, Anderson CM, Hilty K, Webb P, Uht RM, Price Jr RH, Pestell RG, Kushner PJ. Opposing action of estrogen receptors alpha and beta on cyclin D1 gene expression. J Biol Chem. 2002;277(27):24353-60.

32. Planas-Silva MD, Weinberg RA. Estrogen-dependent cyclin E-cdk2 activation through p21 redistribution. Mol Cell Biol. 1997;17(7):4059-69.

33. Worsley SD, Ponder BA, Davies BR. Overexpression of cyclin D1 in epithelial ovarian cancers. Gynecol Oncol. 1997;64(2):189-95.

34. Guerini V, Sau D, Scaccianoce E, Rusmini P, Ciana P, Maggi A, Martini PG Katzenellenbogen BS, Martini L, Motta M, et al. The androgen derivative 5alphaandrostane-3beta,17beta-diol inhibits prostate cancer cell migration through activation of the estrogen receptor beta subtype. Cancer Res. 2005;65(12):5445-53.

35. Weihua Z, Lathe R, Warner M, Gustafsson JA. An endocrine pathway in the prostate, ERbeta, AR, 5alpha-androstane-3beta,17beta-diol, and CYP7B1, regulates prostate growth. Proc Natl Acad Sci U S A. 2002;99(21):13589-94.

36. Pak TR, Chung WC, Lund TD, Hinds LR, Clay CM, Handa RJ. The androgen metabolite, 5alpha-androstane-3beta, 17beta-diol, is a potent modulator of estrogen receptor-beta1-mediated gene transcription in neuronal cells. Endocrinology. 2005;146(1):147-55.

37. Harris HA. Preclinical characterization of selective estrogen receptor beta agonists: new insights into their therapeutic potential. Ernst Schering Found Symp Proc. 2006;1:149-61.

38. Harris HA, Albert LM, Leathurby $Y$, Malamas MS, Mewshaw RE, Miller CP, Kharode YP, Marzolf J, Komm BS, Winneker RC, et al. Evaluation of an estrogen receptor-beta agonist in animal models of human disease. Endocrinology. 2003;144(10):4241-9.

39. Malamas MS, Manas ES, McDevitt RE, Gunawan I, Xu ZB, Collini MD, Miller CP, Dinh T, Henderson RA, Keith Jr JC, et al. Design and synthesis of aryl diphenolic azoles as potent and selective estrogen receptor-beta ligands. J Med Chem. 2004:47(21):5021-40.

40. Mersereau JE, Levy N, Staub RE, Baggett S, Zogovic T, Chow S, Ricke WA Tagliaferri M, Cohen I, Bjeldanes LF, et al. Liquiritigenin is a plant-derived highly selective estrogen receptor beta agonist. Mol Cell Endocrinol. 2008; 283(1-2):49-57.
41. Lattrich C, Schuler S, Haring J, Skrzypczak M, Ortmann O, Treeck O. Effects of a combined treatment with tamoxifen and estrogen receptor beta agonists on human breast cancer cell lines. Arch Gynecol Obstet. 2014;289(1):163-71.

42. Lattrich C, Stegerer A, Haring J, Schuler S, Ortmann O, Treeck O. Estrogen receptor beta agonists affect growth and gene expression of human breast cancer cell lines. Steroids. 2013;78(2):195-202.

43. Beaufort CM, Helmijr JC, Piskorz AM, Hoogstraat M, Ruigrok-Ritstier K, Besselink N, Murtaza M, van IWF HAA, Smid M, et al. Ovarian cancer cell line panel (OCCP): clinical importance of in vitro morphological subtypes. PLoS One. 2014;9(9):e103988.

44. Muller PA, Vousden KH. p53 mutations in cancer. Nat Cell Biol. 2013;15(1):2-8.

45. Berman DM, Karhadkar SS, Maitra A, Montes De Oca R, Gerstenblith MR, Briggs K, Parker AR, Shimada Y, Eshleman JR, Watkins DN, et al. Widespread requirement for hedgehog ligand stimulation in growth of digestive tract tumours. Nature. 2003;425(6960):846-51.

46. Pasca di Magliano M, Hebrok M. Hedgehog signalling in cancer formation and maintenance. Nat Rev Cancer. 2003;3(12):903-11.

47. Pignot $G$, Vieillefond A, Vacher S, Zerbib M, Debre B, Lidereau R, AmsellemOuazana D, Bieche I. Hedgehog pathway activation in human transitional cell carcinoma of the bladder. Br J Cancer. 2012;106(6):1177-86.

48. Fujii K, Ohashi H, Suzuki M, Hatsuse H, Shiohama T, Uchikawa H, Miyashita T. Frameshift mutation in the PTCH2 gene can cause nevoid basal cell carcinoma syndrome. Familial Cancer. 2013;12(4):611-4.

49. Smyth I, Narang MA, Evans T, Heimann C, Nakamura Y, Chenevix-Trench G, Pietsch T, Wicking C, Wainwright BJ. Isolation and characterization of human patched 2 (PTCH2), a putative tumour suppressor gene inbasal cell carcinoma and medulloblastoma on chromosome 1p32. Hum Mol Genet. 1999:8(2):291-7.

50. Worley Jr MJ, Liu S, Hua Y, Kwok JS, Samuel A, Hou L, Shoni M, Lu S, Sandberg EM, Keryan A, et al. Molecular changes in endometriosisassociated ovarian clear cell carcinoma. Eur J Cancer. 2015;51(13):1831-42.

51. Olah J, Vincze O, Virok D, Simon D, Bozso Z, Tokesi N, Horvath I, Hlavanda E, Kovacs J, Magyar A, et al. Interactions of pathological hallmark proteins: tubulin polymerization promoting protein/p25, beta-amyloid, and alphasynuclein. J Biol Chem. 2011;286(39):34088-100.

52. Donev R, Newall A, Thome J, Sheer D. A role for SC35 and hnRNPA1 in the determination of amyloid precursor protein isoforms. Mol Psychiatry. 2007;12(7):681-90.

53. Mercier I, Casimiro MC, Zhou J, Wang C, Plymire C, Bryant KG, Daumer KM, Sotgia F, Bonuccelli G, Witkiewicz AK, et al. Genetic ablation of caveolin-1 drives estrogen-hypersensitivity and the development of DCIS-like mammary lesions. Am J Pathol. 2009;174(4):1172-90.

54. Dey P, Jonsson P, Hartman J, Williams C, Strom A, Gustafsson JA. Estrogen receptors beta1 and beta2 have opposing roles in regulating proliferation and bone metastasis genes in the prostate cancer cell line PC3. Mol Endocrinol. 2012:26(12):1991-2003.

55. Yamashita T, Budhu A, Forgues M, Wang XW. Activation of hepatic stem cel marker EpCAM by Wnt-beta-catenin signaling in hepatocellular carcinoma. Cancer Res. 2007:67(22):10831-9.

56. Youssef KK, Lapouge G, Bouvree K, Rorive S, Brohee S, Appelstein O, Larsimont JC, Sukumaran V, Van de Sande B, Pucci D, et al. Adult interfollicular tumour-initiating cells are reprogrammed into an embryonic hair follicle progenitor-like fate during basal cell carcinoma initiation. Nat Cell Biol. 2012;14(12):1282-94.

57. Kong LN, Zuo PP, Mu L, Liu YY, Yang N. Gene expression profile of amyloid beta protein-injected mouse model for Alzheimer disease. Acta Pharmacol Sin. 2005;26(6):666-72.

58. Reddy PH, McWeeney S, Park BS, Manczak M, Gutala RV, Partovi D, Jung Y, Yau V, Searles R, Mori M, et al. Gene expression profiles of transcripts in amyloid precursor protein transgenic mice: up-regulation of mitochondrial metabolism and apoptotic genes is an early cellular change in Alzheimer's disease. Hum Mol Genet. 2004;13(12):1225-40.

59. Crow JM, Nelson JD, Remington SG. Human lipocalin-1 association with 3H-testosterone and 3H-estradiol. Curr Eye Res. 2009;34(12):1042-9.

60. Seamon V, Vellala K, Zylberberg C, Ponamareva O, Azzarolo AM. Sex hormone regulation of tear lipocalin in the rabbit lacrimal gland. Exp Eye Res. 2008:87(3):184-90.

61. Yang J, Moses MA. Lipocalin 2: a multifaceted modulator of human cancer. Cell Cycle. 2009;8(15):2347-52.

62. Yang J, Bielenberg DR, Rodig SJ, Doiron R, Clifton MC, Kung AL, Strong RK, Zurakowski D, Moses MA. Lipocalin 2 promotes breast cancer progression. Proc Natl Acad Sci U S A. 2009:106(10):3913-8. 